\title{
Coastal Management
}

\section{III}

\section{Crew in the West Coast Groundfish Catch Share Program: Changes in Compensation and Job Satisfaction}

\section{Erin Steiner, Suzanne Russell, Ashley Vizek \& Amanda Warlick}

To cite this article: Erin Steiner, Suzanne Russell, Ashley Vizek \& Amanda Warlick (2018) Crew in the West Coast Groundfish Catch Share Program: Changes in Compensation and Job Satisfaction, Coastal Management, 46:6, 656-676, DOI: 10.1080/08920753.2018.1522495

To link to this article: https://doi.org/10.1080/08920753.2018.1522495

曲 Published online: 08 Jan 2019.

Submit your article to this journal $\pi$

Џ Article views: 41

View Crossmark data $\complement$

Citing articles: 2 View citing articles $\square$ 


\title{
Crew in the West Coast Groundfish Catch Share Program: Changes in Compensation and Job Satisfaction
}

\author{
Erin Steiner ${ }^{a}$, Suzanne Russell ${ }^{b}$, Ashley Vizek ${ }^{c}$, and Amanda Warlick ${ }^{d}$ \\ ${ }^{\mathrm{a} F i s h e r i e s ~ R e s o u r c e ~ A n a l y s i s ~ a n d ~ M o n i t o r i n g, ~ N o r t h w e s t ~ F i s h e r i e s ~ S c i e n c e ~ C e n t e r, ~ N a t i o n a l ~ O c e a n i c ~ a n d ~}$ \\ Atmospheric Administration, Seattle, Washington, USA; ${ }^{b}$ Conservation Biology, Northwest Fisheries \\ Science Center, National Oceanic and Atmospheric Administration, Seattle, Washington, USA; ${ }^{~}$ Pacific \\ States Marine Fisheries Commission in support of NOAA Fisheries, Seattle, Washington, USA; dECS \\ Federal, LLC in support of NOAA Fisheries, Seattle, Washington, USA
}

\begin{abstract}
Catch share programs can have far-reaching effects on coastal communities and the people that rely on fishing income, including crew members. Analysis of management actions affecting crew wages and well-being is often limited due to a dearth of available data. We examine crew-related outcomes during the first six years of the West Coast Groundfish Trawl Catch Share Program using two unique datasets - a mandatory economic survey and a voluntary social science study. We find that impacts on crew compensation differ from other catch share programs due to prior conditions of the fishery and also vary by the target species within the program. The median number of crew positions per vessel increased slightly, annual crew days decreased, and crew wage as a percentage of revenue was nearly unchanged, even with the introduction of new costs. Median daily crew compensation increased from $\$ 514$ per day to $\$ 776$ after implementation of catch shares and annual compensation increased from $\$ 33$ thousand to $\$ 39$ thousand. Many crew members expressed a lack of support for the program and job satisfaction did not rise with increased wages and fewer days at sea, indicating that job satisfaction is likely influenced by more than compensation and effort.
\end{abstract}

\section{KEYWORDS}

catch shares; crew wages; job satisfaction; remuneration

\section{Introduction}

Crew are an essential component of any fishery, but may often be overlooked in fishery management decisions, even for those decisions that could lead to significant structural changes with direct impacts on crew. This failure stems from poor data availability, resulting in little analysis in economics literature about how crew might be impacted by different management regimes (Abbott, Garber-Yonts, and Wilen 2010; Casey et al. 1995; Brandt and Ding 2008; Macinko 2010; Turris 2010). This paucity of data exists in large part because studying crew is difficult; unlike tracking vessel owners through vessel registrations and permits, tracking individual crew members is challenging because crew license systems are rare in federal fisheries (Pollnac, Seara, and Colburn 2015;

CONTACT Erin Steiner erin.steiner@noaa.gov E Fisheries Resource Analysis and Monitoring, Northwest Fisheries Science Center, National Oceanic and Atmospheric Administration, 2725 Montlake Blvd E, Seattle, Washington, 98112, USA.

Color versions of one or more of the figures in the article can be found online at www.tandfonline.com/ucmg. 
Macinko 2010). Overcoming these impediments to learn more about the impacts of regulatory changes on crew is important because they are recognized as a disproportionately vulnerable population (Terkla, Doeringer, and Moss 1988; Copes 1972; Crutchfield 1979). Specifically, catch share programs have been shown to affect crew more than other participants through the loss of jobs associated with a reduction in vessels, changes in compensation and the nature of their position, and shifts in power dynamics within the fishery (Carothers 2015; Carothers and Chambers 2012).

The implementation of catch share programs often results in fewer vessels participating over longer seasons (Abbott, Garber-Yonts, and Wilen 2010; Brandt and Ding 2008) and an increase in the unit value of catch (Wilen and Homans 1994), which can have implications for crew wages and employment in the fishery (Casey et al. 1995; Abbott, Garber-Yonts, and Wilen 2010). Previous studies have shown that catch shares result in both positive and negative outcomes for crew, including increases in compensation for those that remain in the fishery, decreases in the number of jobs, and increases in the total days fished (Casey et al. 1995; Abbott, Garber-Yonts, and Wilen 2010). Abbott, Garber-Yonts, and Wilen (2010) found that overall, crew that remained in the Bristol Bay Red King Crab and Bering Sea Snow Crab fisheries through the transition to catch shares earned higher annual wages, but the piece-rate compensation was lower than before rationalization. In a study of the British Columbia Halibut fishery, Casey et al. (1995) found that the reduction in the number of vessels resulted in a decrease in the number of total crew employed, a decrease in the number of crew per vessel, but an increase in the total number of crew hours fished.

Beyond economic impacts, past research has found that catch shares management changes the nature of crew jobs and crew members' power and status in the fishery (Carothers 2015; Carothers and Chambers 2012). In a study of fishermen in Kodiak, Alaska, Carothers (2015) found that $72 \%$ of the study participants thought crew members had been negatively affected by the quota system. Unlike quota owners who can sell their quota when they leave the fishery, crew members are not similarly compensated and often have few alternative employment options (Carothers 2015; Terkla, Doeringer, and Moss 1988). Furthermore, Carothers (2015) found that the value of skilled labor degraded following catch shares, leading to a loss of power for crew members. Finally, quota systems have been found to make upward mobility for crew members more difficult due to the additional costs and accessibility of quota (Carothers 2015; Macinko 2010). There is also some indication that catch share programs may affect crew job satisfaction or their enjoyment of fishing, which is related to their overall well-being (Pollnac, Seara, and Colburn 2015). For instance, in a small study (ten interviews, five of which were crew) of the West Coast groundfish catch share fishery, Sayre (2017) found that crew job satisfaction was negatively impacted by the quota system, with some members describing a decrease in the amount and predictability of wages due to the added costs associated with the catch share program such as paying for observer coverage and leasing quota.

The way a fishery responds to the transition to catch shares, and consequently the program's effect on crew, is strongly determined by the nature of the fishery prior to implementation, including factors such as stock status and the regulatory framework controlling effort (Reimer, Abbott, and Wilen 2014). Catch share programs are often implemented in response to overcapacity in derby-style fisheries with short fishing seasons (Abbott, Garber-Yonts and 
Wilen, 2010; Homans and Wilen 1997; Birkenbach, Kaczan, and Smith 2017) and a correspondingly low unit value of overall catch (Hackett et al. 2005).

In the case of the U.S. West Coast groundfish trawl fishery that transitioned to a catch share program in 2011, prior management measures had to some extent already addressed overcapacity and the existing race-to-fish (Warlick, Steiner, and Guldin 2018). The non-whiting groundfish component of the trawl fishery was not a derby fishery owing to existing cumulative landings limits that distributed catches throughout the year, and because overcapitalization had already been largely limited by the 1994 Limited Entry program and the 2003 buyback program ${ }^{1}$ that removed nearly $40 \%$ of active vessels from the fishery. As a result, the transition to catch shares coincided with only a modest decrease in the number of active vessels and season length increased only for some subfisheries and actually contracted for others (Errend et al. 2018). Therefore, the impacts of the catch share program on crew were expected to differ from those seen in other fisheries.

The West Coast groundfish trawl fishery includes diverse participants targeting whiting and other non-whiting groundfish species of California, Oregon, and Washington and has a complex management history with numerous measures aimed at reducing capacity and rebuilding overfished stocks (Warlick, Steiner, and Guldin 2018). The Final Environmental Impact Statement (FEIS) for the implementation of the program described crew employment as vulnerable to the proposed management change, a particular concern given that a reduction in jobs could have adverse impacts on isolated communities with few alternative employment opportunities (PFMC and NMFS 2010). In the FEIS, the Pacific Fishery Management Council identified "promoting employment benefits" as a program objective and noted potential impacts on crew, including changes in the number of jobs, shares paid, hours worked, average income, required skills, ability to own quota, and safety at sea.

The scarcity of studies focusing on the effects of catch share programs on crew coupled with the unique implementation of this catch share program underscores the importance of conducting a case study of this program. Census-level annual cost and earnings data collection of vessels and a social survey of fishery participants conducted before and after the implementation of the catch share program provide a unique opportunity to develop a comprehensive picture of how changes in the fishery have impacted crew. Our data facilitate the exploration of four predicted impacts from the FEIS (the number of jobs, shares paid, hours worked, and average income) and two key elements of well-being (job and compensation satisfaction). To provide context to findings, information about crew demographics, income reliance on the fishery, and crew support for and planned participation in the program are also discussed.

\section{Methods}

\section{Data}

The West Coast Groundfish Trawl Catch Share Program motivated the introduction of two surveys administered by the Northwest Fisheries Science Center (NWFSC) of the National Marine Fisheries Service: the Economic Data Collection (EDC) and the Pacific Coast Groundfish Fishery Social Study (PCGFSS). Participation in the EDC Program is 
a regulatory requirement for participants in the West Coast Groundfish Trawl Catch Share Program (Steiner et al. 2017), while the PCGFSS is a voluntary survey. This information is combined with state fish ticket data (ex-vessel revenue, the number of trips, landings weight by species) and the NWFSC At-Sea Hake Observer Program data (landings weight by species, the number of deliveries) to create a comprehensive data set for analysis of industry-level, vessel-level, and individual-level socioeconomic outcomes.

The EDC Program is a census of all vessels in the catch share program, conducted annually. The primary components of the survey are annual costs by category, days at sea, revenue sources in addition to ex-vessel revenue, and vessel characteristics. Crew-specific information includes the number of crew positions, annual compensation, and details about the lay system such as the reported share percentage as well as the cost categories that are deducted from ex-vessel revenue before applying the share percentage. Tracking the nuances of crew turnover or how often crew work on multiple vessels is outside the scope of this analysis, and therefore, we equate a single crew position to a single crew member. While this may oversimplify the complexity in crew wages and job satisfaction across the wide range of vessels and experiences in the fishery, it is the best available data to date. Data from 2009 and 2010 serve as a pre-catch shares baseline, and catch share data are available from 2011 to 2016. All values are reported in inflation-adjusted 2016 dollars.

This analysis includes any vessel that fished in the Limited Entry Trawl Groundfish Fishery (pre-catch shares) or the West Coast Groundfish Trawl Catch Share Program (catch share program), as well as any crew members associated with these vessels. Vessels are categorized into two types, "groundfish" and "whiting." The groundfish vessel category includes the vessels that targeted species such as Dover sole, thornyheads, sablefish, petrale sole, other flatfish, and rockfish. Whiting vessels include any vessel that fished in the shore-based or at-sea whiting fisheries. If a vessel fished in both the whiting and groundfish fisheries, they are classified as a whiting vessel. Each vessel is classified into one of the two categories on an annual basis and can therefore change classifications from year to year.

The PCGFSS is an extensive voluntary survey collecting a wide range of demographic and attitudinal information administered through semi-structured, in-person interviews (Russell, Van Oostenburg, and Vizek 2018). It has been conducted three times: 2010, 2012, and 2015-2016 (hereafter 2016). The sample frame includes all Limited Entry permit owners, quota share owners, and processors holding first receiver site licenses (Table 1). There is no list or registry of fishery participants outside this sample frame; therefore, crew, ${ }^{2}$ equipment providers, and processing plant workers were contacted using a snowball approach. Snowball sampling is commonly used when the population of interest is hard to reach (Bernard 2000; Robson 2002) and has also been used in previous fisheries social studies (Porcelli 2017; Ebel et al. 2018). Although snowball sampling is a nonrandom sampling method and biased toward individuals with many interrelationships, it allows researchers to account for individuals that would not be represented in more traditional sampling methods (Faugier and Sargeant 1997). This is particularly important in the West Coast groundfish trawl fishery as there is no crew registry or any other source of information about crew.

Thirty-seven crew members were surveyed in 2010 and 2012, and 21 were surveyed in 2016. Following the approach of Macinko (2010), coverage for the PCGFSS crew 
Table 1. Source of contact information by study participant type for each of the three Pacific Coast Groundfish Fishery Social Study survey cycles. All crew members were recruited as referrals from individuals in the other participation types. No contact information was available for quota share owners or first receiver site license holders in 2010 because these programs were part of the implementation of the catch share program. Seafood buyer information was used in lieu of first receiver site license information until it became available.

\begin{tabular}{llccr}
\hline & \multicolumn{1}{c}{ Survey year } \\
\cline { 3 - 5 } Source & \multicolumn{1}{c}{ Participant type } & 2010 & 2012 & 2015-2016 \\
\hline NMFS West Coast Regional & Limited Entry trawl permit owners & $X$ & $X$ & $X$ \\
Permit Office & Quota share owners & $X$ & $X$ \\
& Seafood buyers & $X$ & $X$ & $X$ \\
Referrals & First receiver site license holders & $X$ & $X$ & $X$ \\
\hline
\end{tabular}

Table 2. Percentage of vessels with at least one crew member surveyed by the Pacific Coast Groundfish Fishery Social Study, and the total number of unique, active vessels by vessel type, home port state, and time period (pre-catch shares or catch shares). An active vessel is defined as any vessel that fished during the time period, 2009-2010 for the pre-catch share period and 2011-2016 for the catch share period.

\begin{tabular}{|c|c|c|c|c|c|}
\hline \multirow[b]{2}{*}{ Vessel type } & \multirow[b]{2}{*}{ Home port state } & \multicolumn{2}{|c|}{ Pre-catch shares } & \multicolumn{2}{|r|}{ Catch shares } \\
\hline & & $\%$ coverage & Total number of vessels & $\%$ coverage & Total number of vessels \\
\hline \multirow[t]{3}{*}{ Groundfish } & Washington and Alaska & $29 \%$ & 7 & $0 \%$ & 12 \\
\hline & Oregon & $33 \%$ & 54 & $30 \%$ & 62 \\
\hline & California & $24 \%$ & 38 & $20 \%$ & 37 \\
\hline \multirow[t]{3}{*}{ Whiting } & Washington and Alaska & $21 \%$ & 14 & $19 \%$ & 14 \\
\hline & Oregon & $19 \%$ & 26 & $31 \%$ & 21 \\
\hline & California & $33 \%$ & 3 & $0 \%$ & 1 \\
\hline
\end{tabular}

sample is calculated as the percentage of active vessels with a response from at least one crew member (Table 2). The groundfish vessels have higher coverage rates than whiting vessels during the pre-catch share period (30\% compared to $21 \%$ ) and equivalent coverage under catch shares (25\%). Oregon has the highest coverage both before and after implementation of catch shares (29\%). California has the lowest coverage during the pre-catch share period (24\%), and Washington (including a small group of vessels that had home ports in Alaska) has the lowest coverage under catch shares (11\%). Although crew members on Washington and Alaska groundfish vessels were surveyed in 2010, this subset was unavailable in 2012 and 2016 primarily due to outdated contact information. Additionally, the geographic disconnect between researchers and the home ports of these vessels complicated the logistics of connecting with crew. Half of the Washington and Alaska vessels have home ports in Alaska or the south/central coast of Washington, whereas PCGFSS researchers responsible for this geography were stationed in Seattle, Washington. The resulting PCGFSS crew sample for groundfish vessels during catch shares is the most representative of vessels from Oregon and California.

\section{Demographics and fishing reliance}

We use demographic information to characterize crew reliance on fishing and provide contextual information about the crew that participate in the catch share program. In order to determine reliance on fishing, we summarize crew members' age, tenure in the fishery, and percentage of income from fishing. These factors serve as a proxy for 
employment flexibility/mobility. This is relevant when evaluating impacts on crew because we expect that individuals with less flexibility and mobility (i.e., older, more experienced fishermen obtaining most of their income from fishing) would have fewer employment options and be more reliant on the fishery (Pollnac, Bavinck, and Monnereau 2012). There was no expectation that the implementation of the catch share program would change crew age, tenure, or percent of income; therefore, results are presented for all survey years combined. To remove the effect of collecting data over multiple time periods, crew age and length of tenure were standardized to 2010 years for each of the two later surveys (i.e., deducting two years from data collected in the 2012 study and six years from the data collected in the 2016 study).

\section{Crew compensation}

All crew in the catch share program are paid using a lay system. Compensation $(W)$ for each vessel and year is therefore determined by ex-vessel revenue $(R)$, costs $\left(C_{g}\right)$, whether the cost was deducted $\left(D_{g}\right)$ from ex-vessel revenue for each cost group $(g)$, and the crew share percentage $(s)$ as agreed upon at the beginning of the season:

$$
W=\left(R-\sum_{g=1}^{G} C_{g} D_{g}\right) s,
$$

Ex-vessel revenue is the gross payments received by fishing vessels for delivery of fish. We report the total revenue earned in the catch share program by vessel type. Whiting vessel revenue includes earnings from delivering whiting to at-sea motherships and shore-based processors, as well as any non-whiting groundfish revenues earned by whiting vessels. Groundfish vessel revenue only includes revenue from fishing in the non-whiting groundfish component of the catch share program. Vessel counts, the number of crew positions, and total crew days (sum of the number of days at sea per vessel times the number of crew positions) are also reported as context for understanding changes in annual and daily wages.

The total deducted costs are determined by the magnitude of each type of cost $C_{g}$, such as fuel, quota costs, and observer fees and whether the vessel owner chooses to deduct that cost $D_{g}$, coded as 1 if the vessel deducts the cost and 0 if the vessel does not deduct the cost. The median cost deducted, the percent of revenue deducted, and the percent of variable costs that are covered by the crew are summarized. Cost sharing between the vessel and the crew is reported as the share of variable costs because deducting fixed costs is rare and because large fluctuations in fixed costs would obscure changes in deduction patterns. This analysis provides an overall picture of changes in deductions since the implementation of the program. Summaries of fishing costs (those costs that existed before the implementation of the catch share program) and catch share-specific costs are used to help explain changes in the overall trends in deductions.

Crew share percentages are presented as the final element of the lay system contracts. These contracts are negotiated between vessel owners and crew and vary by vessel. The reported percent share is summarized by whether the vessel was owner-operated or whether it was operated with a hired skipper. The contract information and ex-vessel 
revenue allows for analysis of the relative effects of changes in fishing activity versus changes in the nature of the lay system contracts.

We analyze changes in compensation using reported wages, rather than calculating the wage directly with the aforesaid equation. Although the EDC Program collects detailed information about each lay system used, the information collected does not encompass every arrangement and therefore the reported wages are a more accurate measure of wages paid to crew members. Three measures of crew wages are presented, total crew compensation, median annual crew wage, and daily crew wage.

The total crew compensation measures the total benefits accruing to the crew sector and allows for the determination as to whether these benefits have changed since the implementation of the catch share program. The total compensation earned from fishing in all West Coast fisheries by vessels participating in the catch share program is also reported. The wages from other fisheries indicate whether vessels are taking advantage of the additional flexibility provided by the catch share program. Changes in total wages are a measure of the benefits transferred to the crew sector, while average crew payments are more relevant to measures of job and pay satisfaction.

Annual wages from fishing in the catch share program indicate whether the benefits received by individual participants have changed since the implementation of the catch share program. This contrasts with the daily crew wage to determine whether the amount of effort required to receive the same wages has changed under catch shares.

\section{Crew satisfaction and support of the catch share program}

In order to track changes in crew members' job satisfaction and participation in the fishery, we summarize the results of four attitudinal questions asked of crew in the PCGFSS. The first two were phrased as standalone questions and participants were asked to respond "Yes," "No," or "Unsure:" (1) "Do you support the catch share program?" and (2) "Do you plan to continue your participation in the Pacific Coast Groundfish Trawl Fishery?" The second two attitudinal questions center around job and pay satisfaction and were part of a question group phrased as "How would you rate the following items in your role in the commercial fishing industry?" Participants were asked to respond "Poor," "Fair," "Good," or "Excellent" in response to the categories of "Job satisfaction" and "Pay satisfaction." To summarize these results, "Poor" and "Fair" are categorized into one category and "Good" and "Excellent" are combined into a second category. Due to the characteristics of the PCGFSS crew sample (i.e., nonrandom, small sample size, repeated measures, unbalanced), we are unable to test the statistical significance of the results.

\section{Results}

\section{Demographics and fishing reliance}

Crew demographic information, their experience in the fishery, and reliance on fishingrelated income provide context for understanding the implications of observed changes in crew compensation and opinions about the catch share program. Across all PCGFSS survey years and for all vessels, $88 \%$ of respondents obtained $100 \%$ of their income 
Table 3. Number of respondents, median age, median tenure in the fishery, and median percent income from fishing by vessel type for all Pacific Coast Groundfish Fishery Social Study survey years combined. Median absolute deviation is shown in parentheses. Age and tenure are standardized to "2010 years." Several crew fished on both whiting vessels and groundfish vessels and are therefore included in both categories.

\begin{tabular}{lcccc}
\hline Vessel type & Number of respondents & Median age (years) & $\begin{array}{c}\text { Median tenure in } \\
\text { fishery (years) }\end{array}$ & $\begin{array}{c}\text { Median percent income } \\
\text { from fishing (\%) }\end{array}$ \\
\hline Groundfish & 73 & $33(9)$ & $8(7)$ & $100(0)$ \\
Whiting & 23 & $42(11)$ & $14(10)$ & $100(0)$ \\
All vessels & 89 & $36(9)$ & $10(8)$ & $100(0)$ \\
\hline
\end{tabular}

from fishing activities. The median age of crew was 33 years for the groundfish fleet and 42 years for whiting (Table 3). Groundfish vessel crew had a median of eight years of experience fishing in the West Coast groundfish trawl fishery, and whiting crew had 14 years of experience (Table 3 ).

\section{Components of crew compensation}

Ex-vessel revenue, the number of vessels, the number of crew days, and the number of crew positions

The first component of wage calculations is ex-vessel revenue. Ex-vessel revenue for whiting and non-whiting landings is higher under catch shares compared to the pre-catch share period (Figure 1), largely due to a combination of rising whiting total allowable catch (TAC) and higher ex-vessel prices for both whiting and sablefish, particularly in 2011 (Errend et al. 2018). Since the implementation of the catch share program, ex-vessel revenue for groundfish vessels ranged from $\$ 23$ to $\$ 32$ million per year; and due to consolidation in the number of participants (Figure 1), average revenue per groundfish vessel is higher than the pre-catch share period. For whiting vessels, fleet-wide ex-vessel revenue was higher than the pre-catch share period until 2015 (Figure 1) when catch attainment was low. This downturn resulted in ex-vessel revenue values lower than that of the groundfish fleet; however since there are many fewer vessels in the whiting fleet, average ex-vessel revenue per vessel was still higher for whiting vessels.

The number of active vessels decreased from a maximum of 134 in 2009 to 97 in 2015 , with a slight uptick in 2016. There was a net decrease of 15 whiting vessels (32\% change) and 23 groundfish vessels (25\%) between 2009 and 2016 (Figure 1). Despite a decrease in the number of active vessels, the total number of groundfish vessel crew remained the same, on average between the pre-catch share and catch share periods, but ranged from 158 crew positions in 2012 to 184 in 2014 (Figure 1). The average number of crew per vessel increased from $1.9 \mathrm{crew}$ per vessel to $2.3 \mathrm{crew}$ per vessel from baseline to catch share years. This increase in the number of crew per vessel was a result of changes in vessel participation (i.e., vessels with fewer crew positions left the fishery and vessels with more crew positions entered the fishery), rather than a change in the number of crew positions on-board individual vessels. Of the vessels that fished both before and after implementation of the catch share program, 85\% of vessels did not change their crew size. The total number of crew positions decreased by $26 \%$ for whiting vessels, accompanying a comparable decrease in the number of active vessels. Vessels that exited the whiting fishery when the catch share program was implemented 

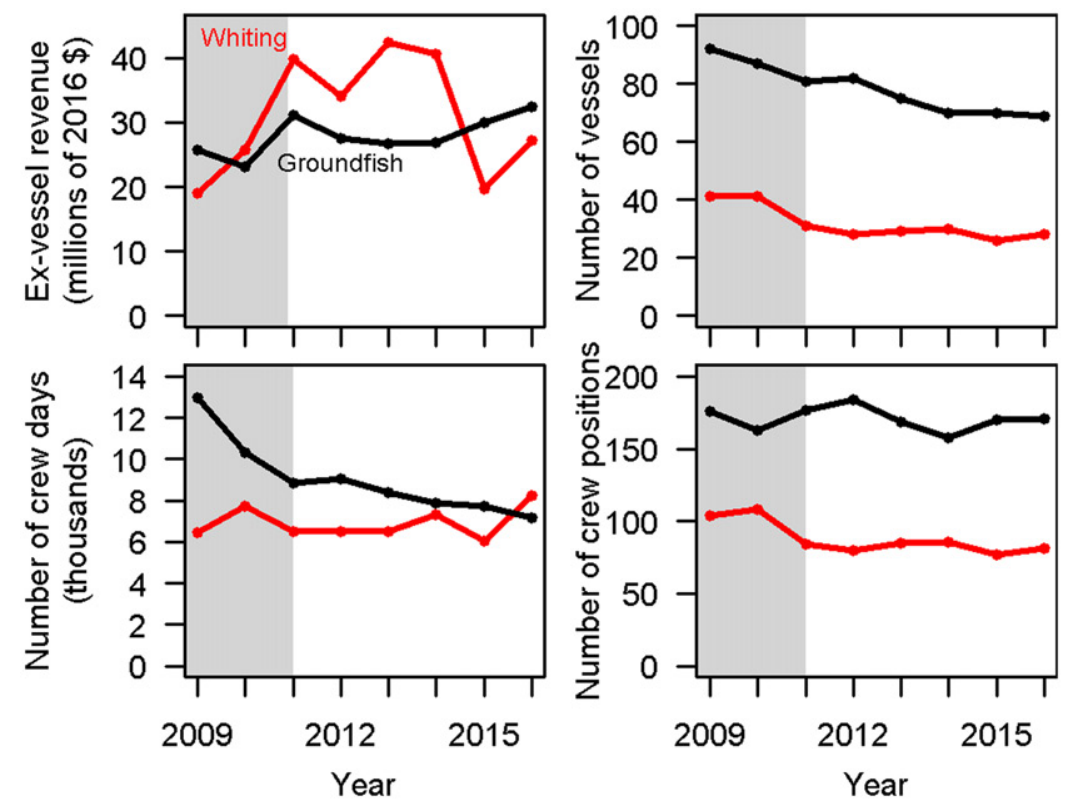

Figure 1. Total ex-vessel revenue (millions of 2016 \$), the number of active vessels, the number of crew days (thousands), and the number of crew positions for groundfish vessels (black) and whiting vessels (red) from fishing in catch share program fisheries. The pre-catch share period is highlighted in gray.

had an average crew size of 2.6, compared to vessels that remained in the catch share program with an average crew size of 2.9 .

Crew days for groundfish vessels decreased from an average of 11,650 crew days per year during the pre-catch share period to 8,000 crew days per year since the implementation of the program (Figure 1). In contrast, the average annual number of crew days for whiting vessels was approximately 7,000 both before and after implementation of the catch share program.

\section{Costs}

Changing costs can affect wages both indirectly as a result of operational decisions and directly as part of wage calculations. The indirect effects of operational decisions are outside the scope of this analysis; instead, we describe changes in the total costs deducted as a result of changes in which types of costs are deducted as well as the magnitude of those costs. The median costs deducted from ex-vessel revenue were higher under the catch share program for both groundfish and whiting vessels (Table 4). This increase is the result of a rise in both fishing-related costs and new catch-share specific costs (Figure 2, top panels) and an increase in the percent of vessels deducting certain types of costs (Figure 2, middle panels).

As a percentage of ex-vessel revenue (Table 4), during the pre-catch share period, groundfish vessels deducted a smaller percentage (13.5\%) compared to whiting vessels (19.3\%), but under catch shares both whiting and groundfish vessels increased the deductions to a median of $22.6 \%$ of ex-vessel revenue. A similar trend exists for cost 
Table 4. Median costs (thousands of 2016 \$) deducted from ex-vessel revenue before calculating crew share, median wage as percent of total ex-vessel revenue, and median percent of variable costs charged to crew by vessel type before and after implementation of the catch share program. Median average deviation is shown in parentheses.

\begin{tabular}{|c|c|c|c|c|c|c|}
\hline \multirow[b]{2}{*}{ Vessel type } & \multicolumn{2}{|c|}{$\begin{array}{l}\text { Median cost deducted } \\
\text { (thousands of } 2016 \$ \text { ) }\end{array}$} & \multicolumn{2}{|c|}{$\begin{array}{c}\text { Percent of revenue } \\
\text { deducted (\%) }\end{array}$} & \multicolumn{2}{|c|}{$\begin{array}{c}\text { Percent of variable costs paid } \\
\text { by crew (\%) }\end{array}$} \\
\hline & $\begin{array}{c}\text { Pre- } \\
\text { Catch Shares }\end{array}$ & Catch Shares & $\begin{array}{c}\text { Pre- } \\
\text { Catch Shares }\end{array}$ & Catch Shares & $\begin{array}{c}\text { Pre- } \\
\text { Catch Shares }\end{array}$ & Catch Shares \\
\hline Groundfish & $\$ 33.0(24.8)$ & $\$ 75.9(48.7)$ & $13.5 \%(8.5)$ & $22.6 \%(8.2)$ & $8.7 \%(5.7)$ & $11.9 \%(4.5)$ \\
\hline Whiting & $87.5(52.9)$ & $217.0(115.5)$ & $19.3(9.3)$ & $22.6(7.0)$ & $12.3(6.1)$ & 11.9 (3.9) \\
\hline All vessels & $44.4(33.8)$ & $100.8(68.4)$ & $15.4(8.9)$ & $22.6(7.8)$ & $9.6(5.9)$ & $11.9(4.3)$ \\
\hline
\end{tabular}

sharing (Table 4), crew on groundfish vessels only paid $8.7 \%$ of total variable costs during the pre-catch share period, compared to $12.3 \%$ for whiting vessels, but under catch shares, the percent increased to $11.9 \%$ for groundfish vessels and remained the same for whiting vessels.

Before the catch share program, the single largest cost deducted was fuel (Figure 2, top panel). During the pre-catch share period, fuel represented $47 \%$ of all costs deducted for groundfish vessels and $67 \%$ for whiting vessels. There was an increase in average fuel costs leading up to 2012 when fuel prices were at their highest $(50-60 \%$ higher than 2009 prices) (Economic Fisheries Information Network 2010; Economic Fisheries Information Network 2013). These costs increased more for whiting vessels than for groundfish vessels. This was a result of the large increase in fishing effort in the whiting sector as well as the disproportionate effect of higher fuel prices because whiting vessels are larger and steam farther than groundfish vessels.

Overall, the total fleet-wide deducted costs were $70 \%$ higher under catch shares compared to the pre-catch share period, an increase from $\$ 6.9$ million to $\$ 14$ million (Figure 2, bottom panels). Much of this can be attributed to increases in fishing by whiting vessels which experienced a $40 \%$ increase in fishing-specific costs, but since the implementation of the catch share program, catch share-specific costs have made up an average of $30 \%$ of total deducted costs. Catch share-specific costs make up a larger portion of total deducted costs for groundfish vessels than for whiting vessels, accounting for $43 \%$ of deducted costs for groundfish vessels compared to $21 \%$ for whiting vessels. The catch share program introduced three new costs to the fishery: cost recovery fees, observer coverage ${ }^{3}$, and quota lease fees. The majority of vessels deducted these costs (Figure 2, middle panels).

The cost to vessels for observer coverage has increased since the implementation of the catch share program as a federal subsidy, introduced during the first year of the program, has been phased out. As a result of this decreasing subsidy, the median annual observer fees increased from just over $\$ 1,000$ per vessel per year to $\$ 8,800$ in 2016 , the first year with no subsidy. The proportion of vessels deducting the cost of observers from the crew share also increased over time from 55\% in $2011-2014$ to $64 \%$ in 2015 and 2016.

Median quota lease fee deductions for groundfish vessels were the highest in 2011 (Figure 2, left panels). This was mostly a result of certain vessels choosing to deduct the cost rather than higher quota lease fees overall. The percentage of groundfish vessels deducting the cost steadily increased from $56 \%$ in the first year of the program to $85 \%$ in 2016. There is very little quota leasing in the whiting fisheries and so the changes in 


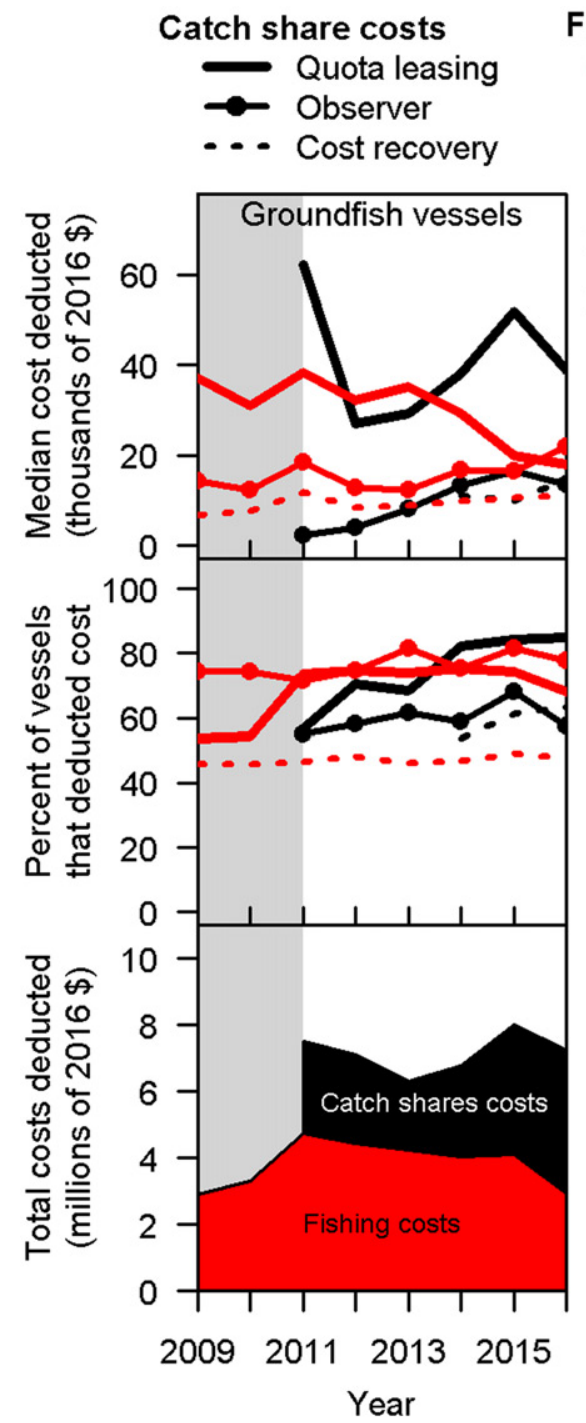

Fishing costs

Fuel and lubrication

$\rightarrow$ Buyback fees

-.. All other costs

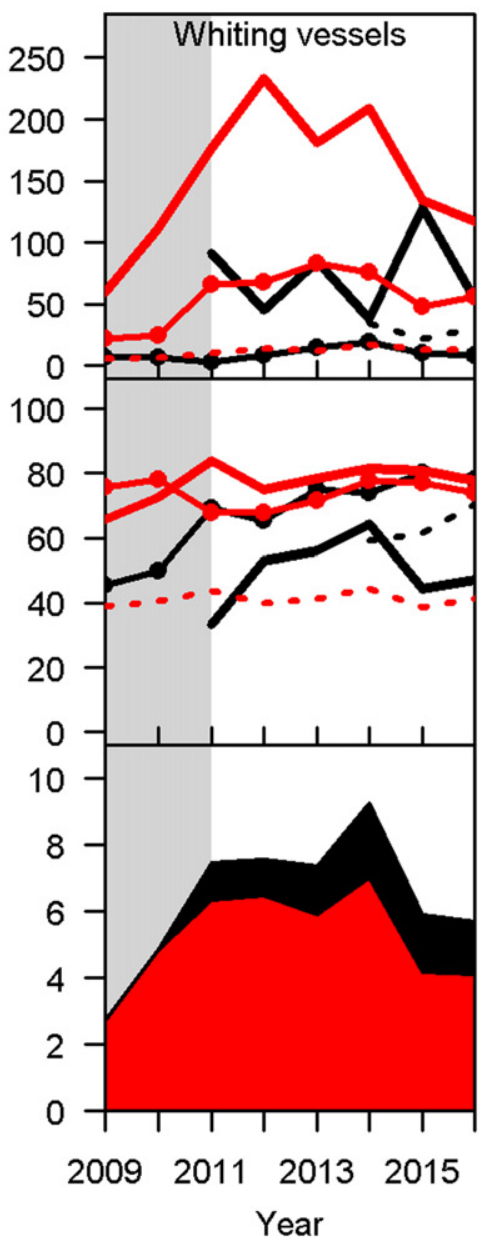

Figure 2. Median cost deducted (top) (thousands of 2016 \$), percent of vessels that deduct each cost (middle), and total costs deducted (bottom) (millions of 2016 \$) by vessel type. Catch share-specific costs are shown in black, and fishing-specific costs are shown in red. The pre-catch share period is highlighted in gray.

costs for whiting vessels are mostly a result of changes in participation in the groundfish fishery rather than changes in the deduction patterns of the whiting vessels themselves. Although half of whiting vessels and almost three-quarters of groundfish vessels deducted quota lease fees, less than $5 \%$ of all vessels deducted the opportunity cost of the quota held at the beginning of the year.

Cost recovery fees were first charged in 2014 and are calculated as a percent of exvessel revenue which varies from year to year. The median cost deducted was the highest for groundfish vessels in 2014 at \$34 thousand per vessel and the highest for whiting vessels in 2016, with a median of $\$ 15$ thousand per vessel. The percent of vessels 
Table 5. The median vessel-reported crew share per crew member by vessel type and whether the vessel was operated by the owner or a hired captain. The median absolute deviation is shown in parentheses. This is the percentage $(s)$ applied to the revenue minus deducted costs reported in Table 4.

\begin{tabular}{llcccc}
\hline Vessel type & Operation type & \multicolumn{2}{c}{ Pre-catch shares } & \multicolumn{2}{c}{ Catch shares } \\
\hline Groundfish & Hired captain & $10 \%$ & $(0.6)$ & $10 \%$ & $(1.0)$ \\
\multirow{3}{*}{ Whiting } & Owner as captain & 13 & $(2.0)$ & 12 & $(3.0)$ \\
& Hired captain & 8 & $(2.0)$ & 7 & $(1.9)$ \\
All vessels & Owner as captain & 8 & $(1.6)$ & 8 & $(1.7)$ \\
& Hired captain & 10 & $(1.5)$ & 8 & $(1.7)$ \\
& Owner as captain & 11 & $(3.5)$ & 8 & $(2.7)$ \\
\hline
\end{tabular}

deducting the cost was higher for whiting vessels (60-70\%) compared to groundfish vessels (50-60\%).

\section{Crew share}

The average crew member on whiting vessels was paid a smaller share than crew members on groundfish vessels (Table 5). The median shares changed very little with the implementation of the catch share program for either groundfish vessels or whiting vessels, but in aggregate there was a decrease. This was the result of a greater number of groundfish vessels exiting compared to whiting vessels. The groundfish vessels continued to pay a larger share when the vessel owner was captain. The share paid by whiting vessels when the vessel was operating with a hired captain decreased from $8 \%$ to $7 \%$.

\section{Wages}

Total crew wages. Total payments to the crew sector from catch share fisheries ${ }^{4}$ increased from $\$ 9.4$ million during the pre-catch share period to over $\$ 12$ million under catch shares (Table 6). There was also an increase in total wages received from all West Coast fisheries, increasing from $\$ 13$ million to $\$ 18$ million. The share of earnings received by crew on groundfish vessels from fishing in catch share fisheries decreased between the pre-catch share period and the catch share period. This is most likely a result of increased flexibility afforded by the catch share program allowing vessels to exploit advantageous fishing conditions in other fisheries such as crab and shrimp. For groundfish vessels, the annual shrimp wages doubled under catch shares, an increase from approximately $\$ 900$ thousand before catch shares to $\$ 2.7$ million since implementation of the catch share program. Wages from fishing in the crab fishery were $75 \%$ greater during the catch share period compared to the pre-catch share period, increasing from $\$ 1.4$ million to $\$ 2.5$ million per year.

In contrast, the whiting vessel crew sector received a larger share of their payments from the catch share fisheries since the implementation of the catch share program, presumably a result of improved fishing conditions in the whiting fishery, garnering increased participation. Many whiting vessels also fish in Alaska, but wages from fishing in Alaska were not included in these analyses. The flexibility to earn revenue from noncatch share fisheries is an important characteristic of the catch share program; however, for the purposes of this paper the remainder of the results section focuses on crew compensation from catch share fisheries. 
Table 6. Total fleet-wide annual crew wage payments (millions of 2016 \$) from catch share fisheries $^{4}$ and in all West Coast fisheries, and the percentage of wages from catch share fisheries by vessel type, before (pre-CS) and after (CS) implementation of the catch share program. Wages from fishing in Alaska are not included.

\begin{tabular}{|c|c|c|c|c|c|c|}
\hline \multirow{3}{*}{ Vessel type } & \multicolumn{4}{|c|}{ Total crew wages } & & \\
\hline & \multicolumn{2}{|c|}{$\begin{array}{l}\text { Catch share fisheries } \\
\text { (millions of } 2016 \$ \text { ) }\end{array}$} & \multicolumn{2}{|c|}{$\begin{array}{l}\text { All West Coast fisheries } \\
\text { (millions of } 2016 \$ \text { ) }\end{array}$} & \multicolumn{2}{|c|}{$\begin{array}{c}\text { Percentage of wages } \\
\text { from catch share fisheries }\end{array}$} \\
\hline & Pre-CS & CS & Pre-CS & CS & Pre-CS & CS \\
\hline Groundfish & $\$ 5.08$ & $\$ 5.95$ & $\$ 7.69$ & $\$ 11.73$ & $66 \%$ & $51 \%$ \\
\hline Whiting & 4.27 & 6.27 & 5.01 & 6.76 & 85 & 93 \\
\hline All vessels & 9.35 & 12.22 & 12.70 & 18.49 & 74 & 66 \\
\hline
\end{tabular}

Annual compensation per crew member. Overall, the median annual wage per crew member increased from $\$ 33$ thousand to $\$ 39$ thousand from baseline to catch share years. The annual median wage for crew on groundfish vessels only increased from $\$ 27$ thousand to $\$ 29$ thousand (Figure 3, top left), whereas crew wages on whiting vessels nearly doubled from $\$ 44$ thousand to $\$ 75$ thousand (Figure 3, bottom left). As described above, most of the changes in whiting crew wages can be attributed to the increases in whiting TAC (Figure 1) that occurred independently from the implementation of the catch share program.

For the 83 vessels that fished during the two year baseline and in at least two years since the implementation of the catch share program, the average increase in annual compensation per crew was $28 \%$. There were 56 groundfish vessels that met this criterion and only experienced a $9 \%$ increase, whereas the 27 whiting vessels experienced a $78 \%$ increase.

Despite the changes described in the previous sections, the percentage of gross ex-vessel revenue paid to crew (both total crew wages divided by total ex-vessel revenue and median of vessel-level crew wage/ex-vessel revenue) only decreased from $20 \%$ to $19 \%$ with the implementation of the catch share program. This implies that overall, increases in ex-vessel revenue counteracted most of the increases in costs deducted as a result of increases in existing costs, new cost categories, and an increase in the number of vessels deducting certain cost categories. At the vessel level, the median change in percentage of ex-vessel revenue paid to crew increased $7 \%$ for groundfish vessels and $2 \%$ for whiting vessels.

Crew compensation per day. There was an increase in median crew wage per day (Figure 3, right panels) for both groundfish vessels and whiting vessels as a result of increases in total wages and decreases in the days fished. The median wage per day on groundfish vessels increased from $\$ 430$ per day to $\$ 730$ per day. The median wage was highest in 2015 , at over $\$ 900$. For the whiting vessels, the crew wage increased from $\$ 620$ to $\$ 868$ per day. Median daily wages were over $\$ 1,000$ from 2011 through 2014, but dropped to below pre-catch share levels in 2015 and 2016. Although the average crew wage per day increased with the implementation of the catch share program, not all crew members experienced increases.

For all vessels combined, vessel-level daily wages increased 68\%, a much larger increase than for annual wages. This was a result of an $82 \%$ increase in daily wages for 
Pre-catch shares

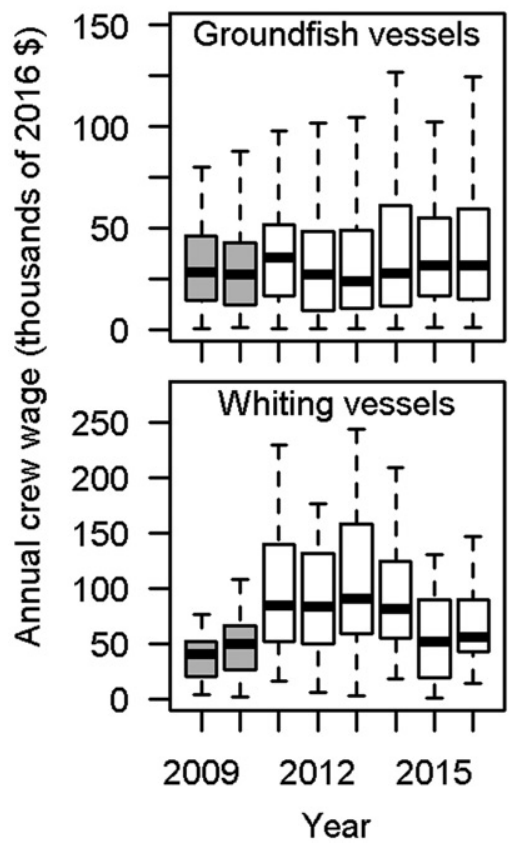

\section{Catch shares}

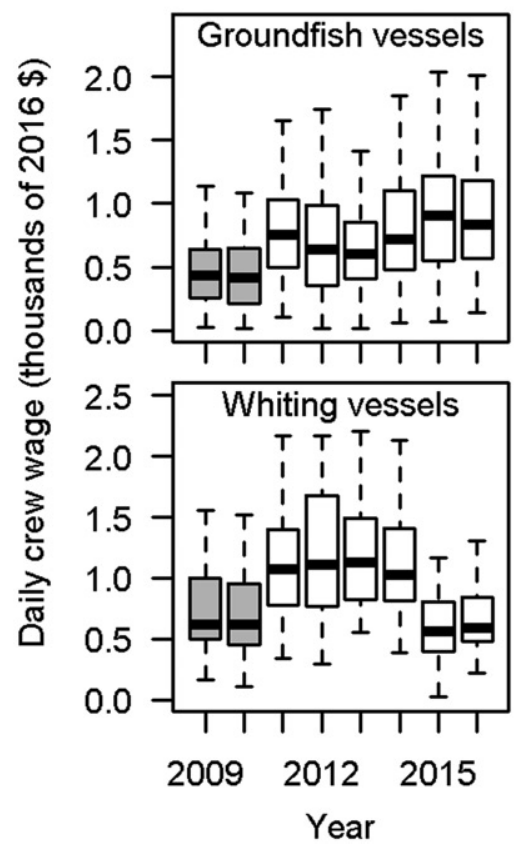

Figure 3. Annual crew wage (thousands of 2016 \$) (left) and daily crew wage (thousands of 2016 \$) (right) by vessel type from 2009 to 2016. The bold line represents the median, the top and bottom of the box represent the 25th and 75th percentiles, and the whisker extends to 1.5 times the inter-quartile range. Outliers are suppressed to protect confidential information. The pre-catch share period is highlighted in gray.

groundfish vessels. These results differ from the change in annual wages because there was a nearly $30 \%$ decrease in vessel-level days at sea for groundfish vessels (Figure 1). The relationship is the reverse for whiting vessels where the vessel-level daily wage only increased by $33 \%$, coupled with a $42 \%$ increase in days at sea.

\section{Support for the catch share program and crew satisfaction}

In the 2010 survey, $89 \%$ of groundfish vessel crew member respondents stated that they would continue fishing in the catch share program, the lowest percentage of positive responses for this item (Figure 4, bottom panel) compared to 100\% in the 2016 survey. The number of whiting vessel crew members who said they would continue fishing was highest in the 2016 survey (100\%), but across the three surveys, the positive response rate for whiting vessel crew never dropped below $91 \%$.

In contrast to the high proportion of crew who stated that they would continue fishing in the catch share program, many individuals stated that they do not support the catch share program (Figure 4, top panel). The proportion of groundfish crew who do not support the catch share program increased from 29\% in 2010 to $59 \%$ in 2016. During the 2010 survey, all of the whiting crew stated that they were unsure about their support of the catch share program. In 2012, only $19 \%$ of whiting crew were unsure about their support of the program, and 50\% supported the program. The percentage of 


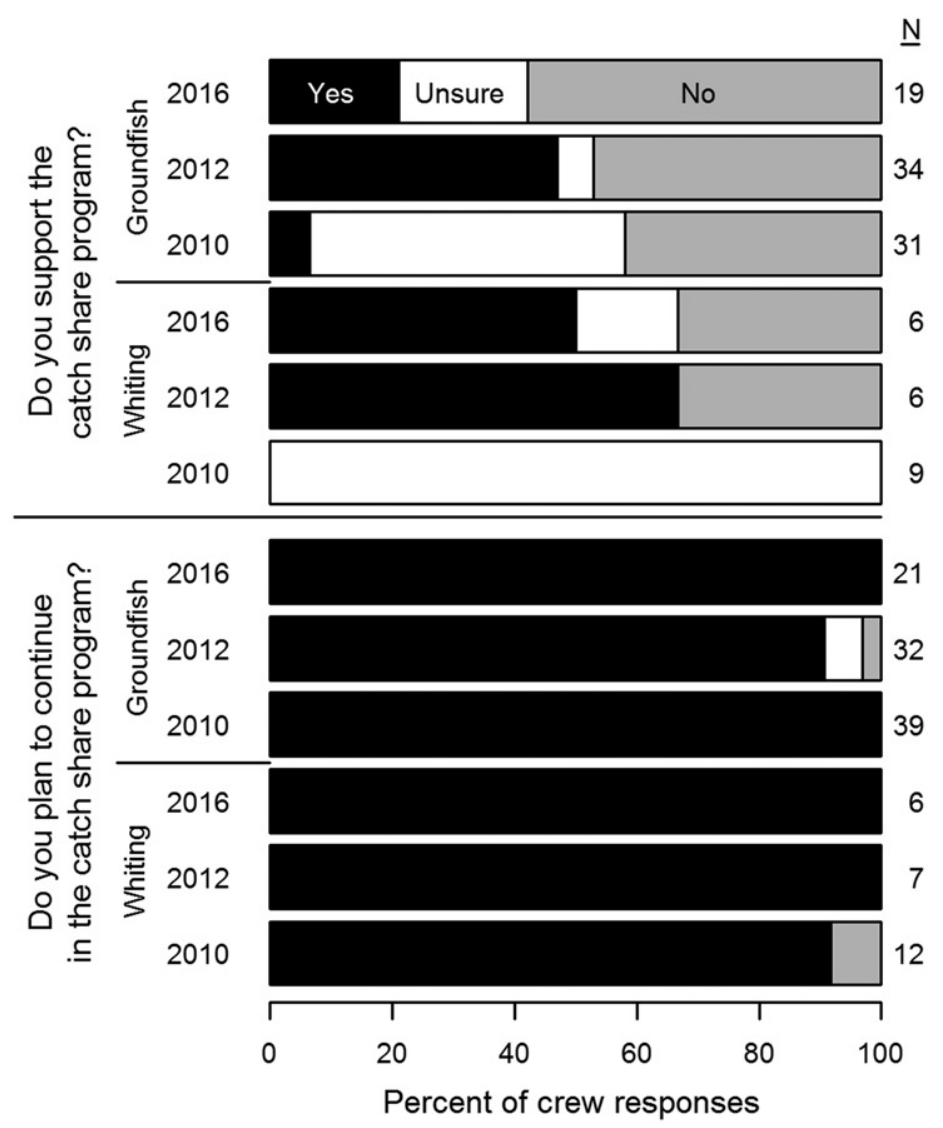

Figure 4. Responses to the questions "Do you support the catch share program"? (top) and "Do you plan to continue fishing in the catch share program?" (bottom) by vessel type for the three survey periods. The number of responses is shown next to each bar. Several crew fished on both whiting vessels and groundfish vessels and are therefore included in both categories.

positive responses increased slightly in 2016 to 54\%. For both whiting and groundfish, the percentage of crew who were unsure about the program - which indicates some level of uncertainty about the program or how it might affect them - was highest during the pre-catch share survey in 2010.

The trends in job and pay satisfaction varied by vessel type and satisfaction category (Figure 5). Job satisfaction did not change for crew on groundfish vessels, with $74-77 \%$ ranking their job satisfaction as "Good" or "Excellent." For whiting vessels, all crew ranked their job satisfaction as "Good" or "Excellent" in 2012, a slight increase from 2010 , but that value dropped to $83 \%$ in 2016 , potentially a result of low catch attainment in 2015 and 2016 (Errend et al. 2018). The percentage of groundfish crew rating pay satisfaction as "Good" or "Excellent" increased steadily through the three survey periods from only 54\% during the 2010 survey to $96 \%$ in the 2016 survey. The trend for whiting vessels was less clear, the highest percentage of crew reporting "Good" or "Excellent" pay satisfaction was observed in 2012 (86\%), and the lowest was in $2010(71 \%)$. 


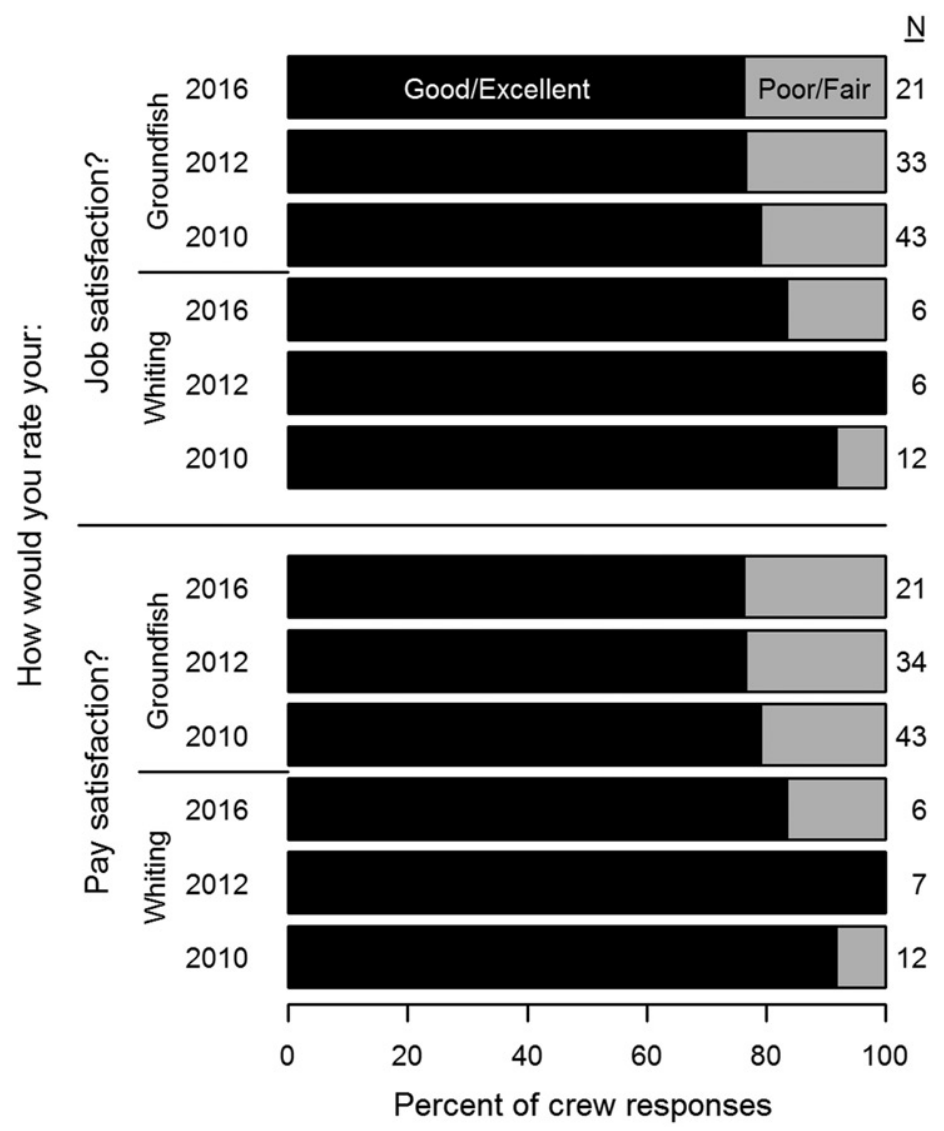

Figure 5. Percentage of respondents who stated that they rate their job satisfaction (top) and pay satisfaction (bottom) as good/excellent (black) or poor/fair (gray) by vessel type. Several crew fished on both whiting vessels and groundfish vessels and are therefore included in both categories.

\section{Discussion}

The crew that remain in the catch share program are arguably better off than before the implementation of the catch share program by nearly all measures. While the implementation of catch shares in most fisheries results in higher wages over longer seasons (Casey et al. 1995), that was not necessarily the case here, largely because the nonwhiting groundfish trawl fishery was not previously operating as a derby. The groundfish vessel crew days actually decreased, while the average ex-vessel revenue per vessel increased. This resulted in an increase in average daily per-vessel ex-vessel revenue which is reflected in the higher daily crew earnings. The trend for whiting vessels is less clear: In the early years of the catch share program, daily crew wages were $75 \%$ higher than pre-catch share levels, but low catch attainment in 2015 and 2016 resulted in decreased daily wages lower than pre-catch share levels.

It is important to note that many of these changes in wages cannot be directly attributed to the implementation of the catch share program. This is especially true for whiting vessels that experienced a dramatic increase in TAC allocated to the sector as well as ex-vessel prices that were higher under catch shares compared to the 
pre-catch shares period (Errend et al. 2018; Guldin et al. 2018). The groundfish sector experienced a slight decrease in the total volume of catch, but maintained ex-vessel revenues close to or slightly higher under catch shares due to growth in ex-vessel prices for some species (Errend et al. 2018). A causal relationship between increases in ex-vessel revenue for groundfish vessels and the catch share program has not yet been established.

In this fishery, increases in crew wages are reflected in crew members' reported satisfaction with their pay. Compared to pre-catch shares levels, more crew (both whiting and groundfish) rated their pay satisfaction as "Good" or "Excellent" in the 2012 and 2016 surveys conducted under catch shares, indicating that not only are crew wages higher, but crew are more satisfied with their compensation. However, we did not find a commensurate increase in responses related to higher job satisfaction as might have been expected. Whiting crew experienced a slight increase in job satisfaction in 2012, which again may be related to increases in TAC allocations, and job satisfaction for groundfish crew remained constant. This highlights two inter-related issues: the multidimensionality of job satisfaction goes beyond compensation and the relationship between compensation and job satisfaction might change depending on your level of investment or ownership. To the first issue, job satisfaction in the fishing industry is commonly modeled as a three-dimensional construct-basic needs (actual earnings, predictability of earnings, safety), social-psychological needs (time away from home, physical fatigue, or healthfulness of the job), and self-actualization (adventure or challenge of the job, sense of autonomy) (Pollnac and Poggie 1988). The lack of improvement in crew members' job satisfaction suggests that while wages and other components of the basic needs dimension are a vital aspect of job satisfaction, they may be counteracted by changes in the other dimensions comprising overall job satisfaction (Pollnac, Seara, and Colburn 2015; Seara et al. 2017).

To the second issue, the lack of improvement in job satisfaction for crew in the catch share program may also signify that catch shares can impact crew differently compared to other fishery participants, particularly those who own quota. For instance, prior to catch shares, crew "ownership" in this fishery may have been recognized informally through investment of labor, particularly given many crew members' age and tenure in the fishery. However, following catch shares, only quota owners receive benefits from the increased security and formal ownership associated with the allocation of quota shares. This is supported by research on the British Columbia halibut fishery, where job satisfaction and the enjoyment of fishing increased among $79 \%$ of license and quota holders with the implementation of individual vessel quotas (Casey et al. 1995). More research on both crew and quota owners in the same fishery could further elucidate the connection between pay and job satisfaction depending on one's ownership status in the fishery.

Despite increases in crew wages, higher pay satisfaction, and high (but not increasing) job satisfaction following catch shares, a relatively small proportion of crew expressed support for the catch share program. In the 2010 survey, the majority of crew were unsure about their level of support for the program. The high percentage of "unsure" responses may be related to (1) an inability to form an opinion about the program due to a lack of information about the program prior to implementation or (2) adequate 
information about the program, but uncertainty about how the program will impact them. Although decreases in the percentage who were unsure about the program led to increases in both the percentage supporting and not supporting the program, support for the program never exceeded 50\% for groundfish crew and remained at or around $50 \%$ for whiting crew. In 2016, less than 25\% of groundfish crew supported the program - a seemingly low percentage given increases in wages. Similar to our discussion of job satisfaction, this suggests that other factors beyond compensation may affect crew support for the program. Although only half of crew members support the program, few reported plans to leave the fishery. Crew members may perceive that the benefits they derive from the fishery outweigh the negative aspects such that "it would take a lot to make them [fishermen] leave the occupation of fishing altogether" (Pollnac, Seara, and Colburn 2015: 89). Alternatively, this may be an indication of an inability to leave the fishery due to a lack of other employment options and a substantial number of years already invested in the industry. We found that crew in the West Coast groundfish trawl fishery are highly invested in the fishery-most have at least ten years of experience in the fishery and obtain at least $95 \%$ of their income from fishing. This represents a significant investment of human capital, both before and during catch shares. This level of dependence on the fishery may limit a crew member's ability to make job changes (Marshall et al. 2007). As the catch share program continues to mature, future research should continue to explore the disconnect between the economic gains crew receive from the catch share program and their reported lack of support for the program.

A major concern about catch share programs is the cost of quota to crew members (Casey et al. 1995). Quota trading programs introduce the cost of leasing quota that may be deducted from the ex-vessel revenue before they are paid. Several studies have shown that most vessels deduct the cost of leasing quota (Casey et al. 1995; Abbott, Garber-Yonts, and Wilen 2010), similar to results presented here. In the West Coast, we found that even when quota costs are deducted, the increases in ex-vessel revenue to the boat offset increased quota costs and result in higher crew wages despite the added costs. This is consistent with findings in the Alaska crab fisheries (Abbott, GarberYonts, and Wilen 2010), the Mid-Atlantic surf clam fishery (Brandt and Ding 2008), and the British Columbia halibut fishery (Casey et al. 1995), but not the Pinkerton and Edwards (2009) analysis of British Columbia halibut fishery. Contrary to economic theory (Casey et al. 1995; Brandt and Ding 2008), we found that vessels often do not deduct the opportunity cost of quota (Abbott, Garber-Yonts, and Wilen 2010; Brandt and Ding 2008). If vessels were to begin deducting the opportunity cost of quota that is owned by vessel operators, it is likely that increases in ex-vessel revenue would no longer offset increases in quota costs deducted.

While crew generally do not have a strong voice in management, they remain an essential component of the fishery and contribute to the economies and culture of the fishing communities in which they reside. In many catch share programs, crew are not allocated quota and are impacted differently by catch shares than fishery participants who own quota. If managers are concerned about the resilience and sustainability of coastal communities, they should consider how management actions impact not only vessel, license, permit, and quota owners, but also crew members. 
The crew surveyed by the PCGFSS are a nonrandom sample recruited through snowball sampling and are therefore not a statistically representative sample of all crew in the fishery. In particular, crew that have left the fishery and crew based on Washington and Alaska groundfish vessels since the implementation of catch shares are under-represented. Unlike asset owners (i.e., Limited Entry Permit, quota share, and vessel owners, and first receiver site license holders), crew are not currently tracked in the West Coast groundfish fishery (and most other fisheries). A crew license system, similar to the Alaska Department of Fish and Game crew license system ${ }^{5}$, where each individual crew member is required to obtain a license to participate in the fishery, would provide contact information and demographic information about all crew. The license system would provide more accurate information about the total number of people employed by the fishery and census-level information about where crew live, an essential component of accurate impact analysis. A robust data collection from crew, made possible by a crew license system, would improve policy makers' ability to make informed decisions and could potentially empower crew to take a more active role in managing fisheries.

\section{Notes}

1. In 2003, the fleet voted to conduct a vessel and permit buyback program to remove 91 vessels and 239 permits from the fishery. This was financed partially with a loan from the U.S. Federal Government to be repaid by with a $5 \%$ fee on all groundfish landings (Holland, Steiner, and Warlick 2017).

2. For the purposes of this paper, we only include individuals who self-identified as crew on an active catch share vessel and stated that they did not own a vessel. Retired crew or crew that no longer participate in the fishery is not represented.

3. Catcher vessels delivering Pacific whiting to motherships at-sea were paying for observer coverage before the implementation of the catch share program.

4. For simplicity, we refer to all fisheries executed with a limited entry groundfish permit with a trawl endorsement a "catch share fishery" regardless of when the fishery was prosecuted.

5. Alaska Department of Fish and Game crew member license information online at http:// www.adfg.alaska.gov/index.cfm?adfg=fishlicense.crewmember, accessed 5.23.2018.

\section{References}

Abbott, J. K., B. Garber-Yonts, and J. E. Wilen. 2010. Employment and remuneration effects of IFQs in the Bering Sea/Aleutian Islands crab fisheries. Marine Resource Economics 25(4): 333-54.

Bernard, H. R. 2000. Social research methods: Qualitative and quantitative approaches. Thousand Oaks, Calif.: SAGE.

Birkenbach, A. M., D. J. Kaczan, and M. D. Smith. 2017. Catch shares slow the race to fish. Nature 544(7649):223.

Brandt, S., and N. Ding. 2008. Impact of property rights on labor contracts in commercial fisheries. Ocean \& Coastal Management 51(11):740-8.

Carothers, C. 2015. Fisheries privatization, social transitions, and well-being in Kodiak, Alaska. Marine Policy 61:313-22. doi:10.1016/j.marpol.2014.11.019.

Carothers, C., and C. Chambers. 2012. Fisheries privatization and the remaking of fishery systems. Environment and Society: Advances in Research 3(1):39-59.

Casey, K. E., C. M. Dewees, B. R. Turris, and J. E. Wilen. 1995. The effects of individual vessel quotas in the British Columbia halibut fishery. Marine Resource Economics 10(3):211-30.

Copes, P. 1972. Factor rents, sole ownership and the optimum level of fisheries exploitation. The Manchester School 40(2):145. http://hdl.handle.net/10535/3234. 
Crutchfield, J. A. 1979. Economic and social implications of the main policy alternatives for controlling fishing effort. Journal of the Fisheries Research Board of Canada 36(7):742-52.

Ebel, S. A., Beitl, C. M. J. Runnebaum, R. Alden., and T. R. J. 2018. The power of participation: Challenges and opportunities for facilitating trust in cooperative fisheries research in the Maine lobster fishery. Marine Policy 90:47-54.

Economic Fisheries Information Network. 2010. West coast and Alaska marine fuel prices 20072009 annual report. Portland, OR: Pacific States Marine Fisheries Commission. http://www. psmfc.org/efin/docs/2009FuelPriceReport.pdf.

Economic Fisheries Information Network. 2013. West coast and Alaska marine fuel prices 20102012 annual report. Portland, OR: Pacific States Marine Fisheries Commission. http://www. psmfc.org/efin/docs/2012FuelPriceReport.pdf.

Errend, M., L. Pfeiffer, E. Steiner, M. Guldin, and A. Warlick. 2018. Economic outcomes for harvesters under the West Coast groundfish trawl catch share program: Have goals and objectives been met? Coastal Management 46(6).

Faugier, J., and M. Sargeant. 1997. Sampling hard to reach populations. Journal of Advanced Nursing 26(4):790-7.

Guldin, M., A. Warlick, M. Errend, L. Pfeiffer, and E. Steiner. 2018. Shorebased processor outcomes under catch shares. Coastal Management 46(6).

Hackett, S. C., M. J. Krachey, S. Brown, and D. Hankin. 2005. Derby fisheries, individual quotas, and transition in the fish processing industry. Marine Resource Economics 20(1):47-60. doi: 10.1086/mre.20.1.42629458.

Holland, D. S., E. Steiner, and A. Warlick. 2017. Can vessel buybacks pay off: An evaluation of an industry funded fishing vessel buyback. Marine Policy 82:8-15. doi: 10.1016/ j.marpol.2017.05.002.

Homans, F. R., and J. E. Wilen. 1997. A model of regulated open access resource use. Journal of Environmental Economics and Management 32(1):1-21.

Macinko, S. 2010. Fisheries 'rationalization' and crew: Workplace dynamics and compensation, what can we learn? NPRB Project 725. Final Report.

Marshall, N. A., D. M. Fenton, P. A. Marshall, and S. G. Sutton. 2007. How resource dependency can influence social resilience within a primary resource industry. Rural Sociology 72(3): 359-90.

PFMC (Pacific Fishery Management Council) and (National Marine Fisheries Service) NMFS 2010. Rationalization of the pacific Coast groundfish limited entry trawl fishery; final environmental impact statement including regulatory impact review and initial regulatory flexibility analysis. Portland, OR: Pacific Fishery Management Council.

Pinkerton, E., and D. N. Edwards. 2009. The elephant in the room: the hidden costs of leasing individual transferable fishing quotas. Marine Policy 33(4):707-13. doi:10.1016/ j.marpol.2009.02.004.

Pollnac, R. B., and J. J. Poggie. 1988. The structure of job satisfaction among new England fishermen and its application to fisheries management policy. American Anthropologist 90(4): $888-901$.

Pollnac, R. B., T. Seara, and L. L. Colburn. 2015. Aspects of fishery management, job satisfaction, and Well-Being among commercial fishermen in the northeast region of the United States. Society \& Natural Resources 28(1):75-92.

Pollnac, R., M. Bavinck, and I. Monnereau. 2012. Job satisfaction in fisheries compared. Social Indicators Research 109(1):119-33.

Porcelli, A. M. 2017. Comparing bonding Capital in new England groundfish and scallop fisheries: Differing effects of privatization. Marine Policy 84:244-50.

Reimer, M. N., J. K. Abbott, and J. E. Wilen. 2014. Unraveling the multiple margins of rent generation from individual transferable quotas. Land Economics 90(3):538-59.

Robson, C. 2002. Real World Research. 2nd ed. Malden: Blackwell Publishing.

Russell, S., M. Van Oostenburg, and A. Vizek. 2018. Adapting to catch shares: Perspectives of West Coast groundfish trawl participants. Coastal Management 46(6). 
Sayre, C. 2017. Catch share policy and job satisfaction in the west coast groundfish trawl fishery. Thesis, Seattle, WA: University of Washington. http://hdl.handle.net/1773/38653. https://digital. lib.washington.edu/researchworks/bitstream/handle/1773/38653/Sayre_washington_0250O_16809. pdf? sequence $=1$ \&isAllowed $=\mathrm{y}$.

Seara, T., R. B. Pollnac, J. J. Poggie, C. Garcia-Quijano, I. Monnereau, and V. Ruiz. 2017. Fishing as therapy: Impacts on job satisfaction and implications for fishery management. Ocean \& Coastal Management 141:1-9.

Steiner, E., M. Guldin, A. Warlick, and P. Lisa. 2017. Economic Data Collection Program Catcher Vessel report (2009-2015). Seattle, WA: Northwest Fisheries Science Center. https://www.nwfsc. noaa.gov/research/divisions/fram/documents/EDC_Catcher_Vessel_Report_June_2017.pdf.

Terkla, D. G., P. B. Doeringer, and P. I. Moss. 1988. Widespread labor stickiness in the new England offshore fishing industry: Implications for adjustment and regulation. Land Economics 64(1):73-82.

Turris, B. R. 2010. A rejoinder to E. Pinkerton et Al., the elephant in the room: the hidden costs of leasing individual transferable fishing quotas. Marine Policy 34(3):431-6.

Warlick, A., E. Steiner, and M. Guldin. 2018. History of the West Coast groundfish trawl fishery: Tracking socioeconomic characteristics across different management policies in a multispecies fishery. Marine Policy 93:9-21. doi:10.1016/j.marpol.2018.03.014.

Wilen, J. E., and F. R. Homans. 1994. Marketing losses in regulated open access fisheries. In Proceedings of the Sixth Conference of the International Institute of Fisheries Economics and Trade. Vol. 11. Paris, France. 